\title{
Histological and Electron Microscopical Observations on the Testis and Male Accessory Glands of Poecilimon ataturki Ünal, 1999 (Orthoptera, Tettigoniidae)
}

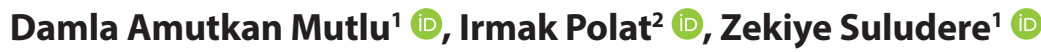 \\ 'Gazi University, Faculty of Science, Department of Biology, Ankara, Turkey \\ ${ }^{2}$ Çankırı Karatekin University, Faculty of Science, Department of Biology, Çankırı, Turkey
}

ORCID IDs of the authors: D.A.M. 0000-0002-4780-8520; I.P. 0000-0001-7230-4589; Z.S. 0000-0002-1207-5814

Please cite this article as: Amutkan Mutlu D, Polat I, Suludere Z. Histological and Electron Microscopical Observations on the Testis and Male Accessory Glands of Poecilimon ataturki Ünal, 1999 (Orthoptera, Tettigoniidae). Eur J Biol 2021; 80(2): 75-81. DOI: 10.26650/EurJBiol.2021.1001795

\begin{abstract}
Objective: The literature has many studies in the world about the morphology and histology of insect tissues, especially structures related to reproductive systems. However, there are no studies about the biology of Poecilimon ataturki Ünal, 1999 (Orthoptera, Tettigoniidae). For this reason, we aimed that the morphology and the structure of the testes and the accessory glands in P. ataturki are revealed.
\end{abstract}

Materials and Methods: In the present study, the histology and morphology of organs of the reproductive system in male $P$. ataturki, an endemic species in Turkey was examined by light microscope, scanning electron microscope, transmission electron microscope, and stereomicroscope.

Results: The reproductive system of male $P$. ataturki is composed of two testes, two vas deferens and short and long accessory glands. Each testis includes numerous follicles where the sperm generation occurs in. There are cysts in the follicles, one of which is in a particular sperm development. 3 different development stages are observed in follicles as growth zone, maturation zone and transformation zone. During these developmental stages, first spermatocytes reproduce by mitosis, and then they turn into spermatids by meiosis. Spermatozoa are also formed by the transformation of spermatids. Thus, the stages of spermatogenesis and spermiogenesis are completed. The accessory glands, whose main task is to produce secretion in order to facilitate the feeding of sperm and their transfer to the female, consist of many tubular structures, long and short. It is seen that it consists of single-layered epithelial tissue in cross sections of the accessory gland tubules.

Conclusion: As a consequence of this work, it has been evinced that male reproductive system elements belonging to $P$. ataturki show high similarity with the male reproductive systems of other species in the Tettigoniidae family.

Keywords: Male reproductive system, light microscopy, scanning electron microscopy, transmission electron microscopy, insect

\section{INTRODUCTION}

Studying the reproductive systems of the insects is central to bring out their population above threshold levels for endangered species. The male reproductive system has three main functions. These are to produce sperm by the male reproductive cells, to manufacture the protective fluid around the sperm via the glands, and to transfer the sperms that are produced to the female reproductive system (1-5).

Testes in order Orthoptera are made up of approximately 300-350 follicles which are tube or finger-shaped structure $(2,4,6)$. There are cells in different stages of development in a testicular follicle. The germ cells which found at the distal side of follicles are called the sper- 
matocytes. The spermatocytes are comprised by the mitotic division and their numbers are increased. After that, spermatocytes located at the middle zone of testicular follicles undergo the meiosis and the spermatids occur. In the proximal side of the follicles, the spermatids are finally differentiated to the mature form, spermatozoa. The spermatozoa become mature and after that heads of sperm join together. This structure is named as spermatodesm $(4,7,8)$.

The male accessory glands in insects play an important role for male fertility (9). It is the essential source of the production of proteinaceous secretions, called as accessory gland proteins $(5,9,10)$. The accessory glands proteins are important for the competition between sperm during the mating. This situation is the major factor that affects to the male reproductive success $(3,10)$.

Poecilimon ataturki Ünal, 1999 is an endemic species in Turkey belonging to the Tettigoniidae family (Orthoptera). Previous studies in the literature indicate that the P. ataturki is distributed in Bolu, Çankırı, Kastamonu, and Karabük Provinces (11-15). The name of P. ataturki is given by Prof. Dr. Mustafa Ünal in honor of Mustafa Kemal Atatürk, the founder of the modern Republic of Turkey in 1923 (11).

There are many literatures are found relevant to the taxonomy, the systematic, and the distribution of this species. However, there are no studies about the biology (such as alimentary system, reproductive organs of male and female individuals) of this species. For this purpose, the morphology and the structure of the testes that produce sperm and the accessory glands that manufacture seminal fluids those mix with sperm in $P$. ataturki are the subject of this paper.

\section{MATERIALS AND METHODS}

\section{Supply of the Tissues}

Adult individuals of $P$. ataturki were taken using a sweep net in Bolu province, Hamidiye Village in July 2019. Five male were anesthetized via the fumes of ethyl acetate. Some of the testes and male accessory glands were dissected in Na-PBS ( $\mathrm{pH} 7.2$ ) and some in $70 \%$ ethanol under stereomicroscope.

\section{Light Microscope (LM) Analysis}

Some of the specimens were fixed in formaldehyde (10\%), dehydrated and blocked in paraffin. The sections $(5-6 \mu \mathrm{m})$ were taken and were stained with Mallory's trichrome and routine staining, Hematoxylin-Eosin (H\&E). Ultimately, the photos were shot with an Olympus BX51 photomicroscope in Gazi University.

Semi-thin sections taken from araldite blocks prepared in accordance with the procedure given below for transmission electron microscope (TEM) were stained with $1 \%$ methylene blue to reveal general histological organization.

\section{Scanning Electron Microscope (SEM) Analysis}

For the SEM investigations, the testes and male accessory glands were firstly fixed in $5 \%$ glutaraldehyde $(\mathrm{pH} 7.2)$ and were dehydrated. In following process, the specimens were dried with critical point dryer (Polaron CPD 7501). Dried specimens were coated with gold (Polaron SC 502). The testes and male accessory glands were finally examined with SEM (JEOL JSM 6060 $\mathrm{LV}$, accelerating voltage 5-10 kV). The observations were done in Prof. Dr. Zekiye Suludere Electron Microscope Center in Gazi University.

\section{Transmission Electron Microscope (TEM) Analysis}

For the TEM observations, testis and accessory glands were first fixed twice: in 5\% glutaraldehyde and then in 1\% osmium tetroxide. After the fixation process, they were dehydrated and were embedded in Araldite blocks. Afterwards, the ultrathin sections were taken from the blocks with using ultramicrotome. Then, they were double stained with lead citrate and uranyl acetate dyes. The examinations with TEM (JEOL JEM 1400, accelerating voltage $80 \mathrm{kV}$ ) were done in Prof. Dr. Zekiye Suludere Electron Microscope Center in Gazi University.

\section{RESULTS}

The internal reproductive structures of male $P$. ataturki are made up of paired testes which are covered by a peritoneal sheath and aerated by several tracheoles, paired vas deferens, and as well as accessory glands (Figure 1). The testes which lay across the body cavity are elongated ovoid in form (Figure 1). Each testis is coated by an epithelium.

The cells in different stages of development are discriminated in several testicular follicles which are found each testis. The cysts consist of grouping of germ cells in the same growth stage (Figure 2A-B). The cells called spermatogonia are located in the germarium region at the distal end of the follicle. Other developmental stages are growth, maturation and transformation zones. The cells in here are spermatocytes, spermatids and spermatozoa in respectively. Spermatocytes are diploid cells with

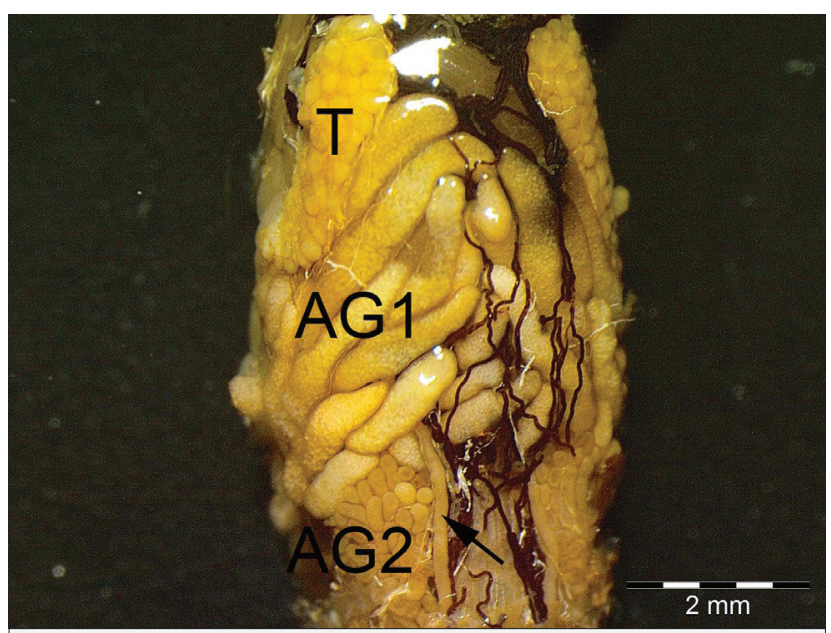

Figure 1. The general stereomicroscopic view of the male reproductive system in $P$. ataturki. T: testis, AG1: long accessory glands, AG2: short accessory glands, arrow: vas deferens, Scale bar $=2 \mathrm{~mm}$. 

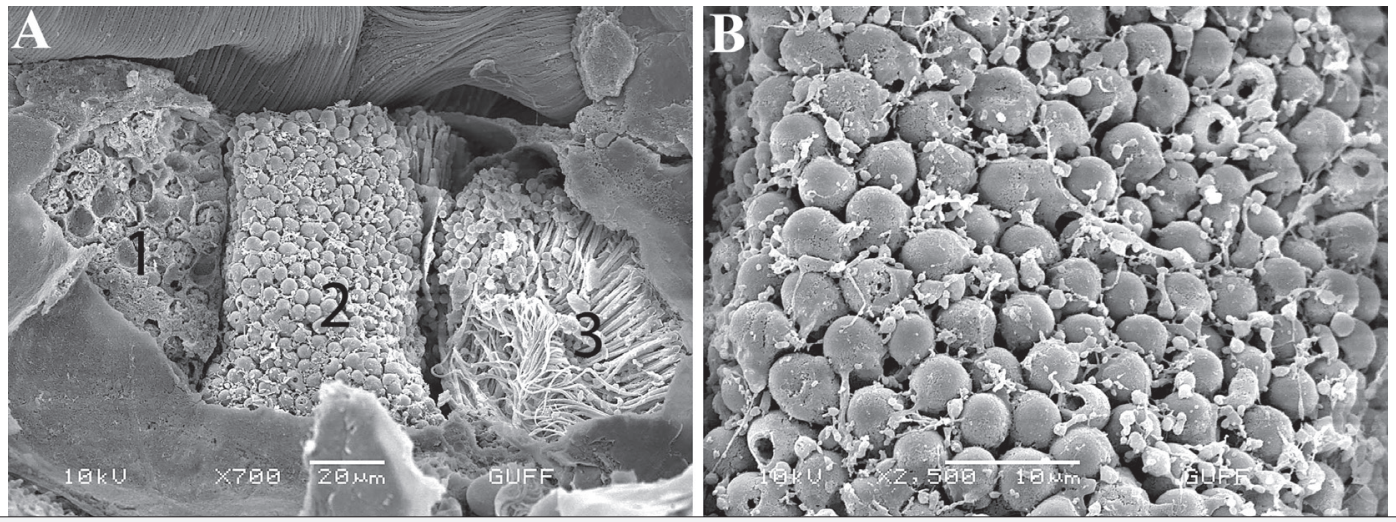

Figure 2. A. The SEM image of the cyst with different stages of development in the testicular follicle. 1: spermatocytes before the meiosis 2: early spermatids, 3: spermatozoa, Scale bar=20 $\mu \mathrm{m}$; B. The SEM image of early spermatids with no tail, Scale bar=10 $\mu \mathrm{m}$.

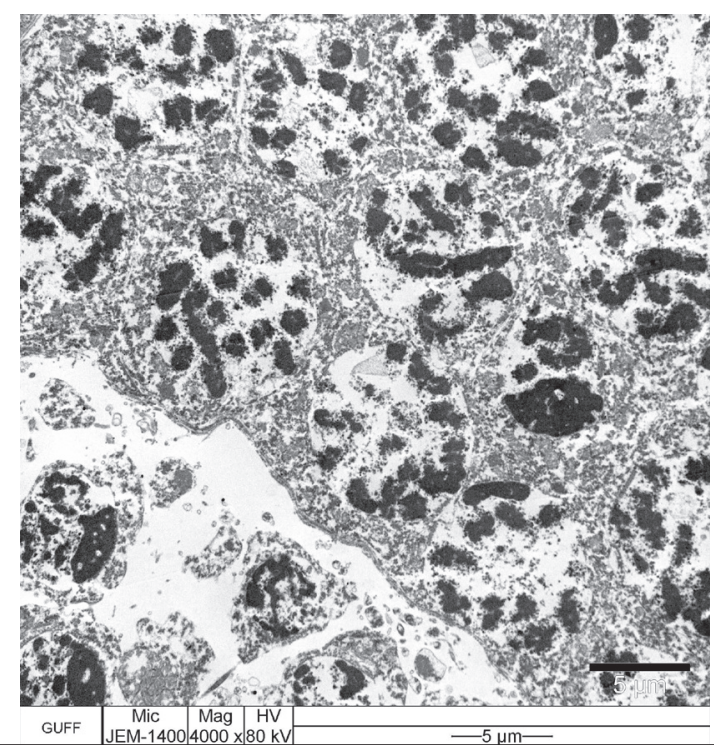

Figure 3. The TEM image of the cyst with spermatocytes, Scale bar $=5 \mu \mathrm{m}$. large spherical nuclei without tails that reproduce by mitosis in cysts in the growth zone. Before meiosis, the nucleus of cells looks as if to be fragmented TEM micrograph (Figure 3). When it comes to the maturation zone, spermatocytes form spermatids as a result of meiosis, which are haploid. The transformation of spermatids is characterized by tail formation. The spermatids in the early stage look like cells with elliptical nucleus which is located in the midst of the cell and no tail (Figures 2B, 4A-B). In the late stage of spermatids, the thin tail structure starts to be apparent and cells have a head beginning to elongate and an elongated tail (Figures 4C, 5). When the transformation of the spermatids is finished in the transformation zone, the spermatozoa occur. During the transformation of spermatids into sperm cells or spermatozoa, the head of the sperm completes elongation (Figure 6A-B). The axoneme and two mitochondrial derivates appear along the flagella in the cross sections of the mature sperm cells (Figure 4C).

The acrosome region is seen in the apex of the sperm head. This region is shirt collar in shape and the hole can be observed close to the tip of the acrosome (Figure 6A-B). Sperm heads are

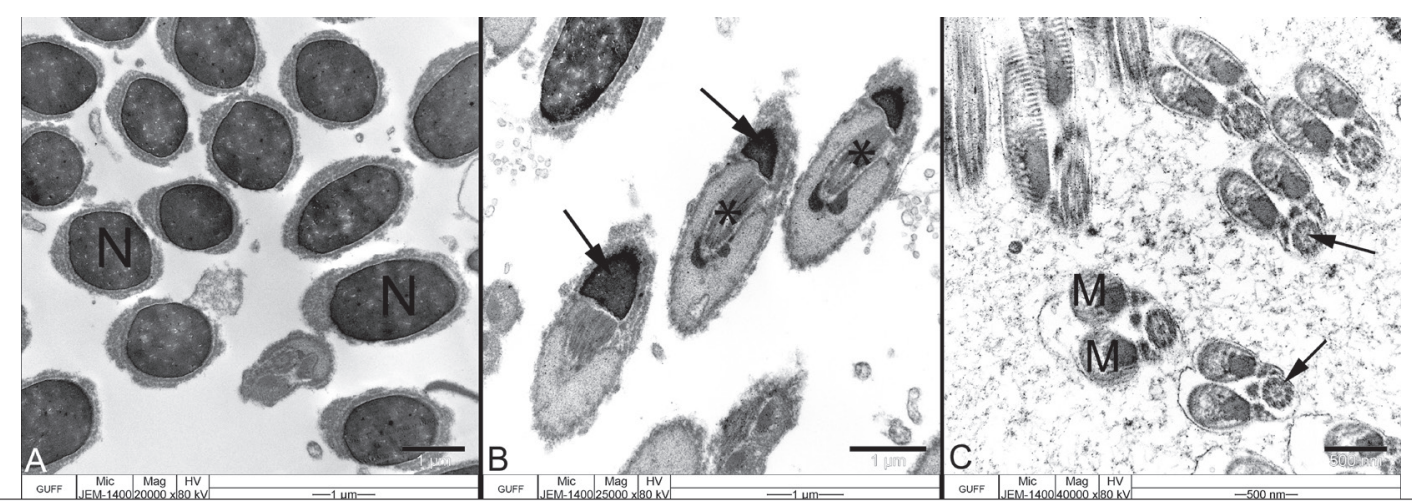

Figure 4. A. The TEM image of the beginning of tail formation in spermatids, N: nucleus, Scale bar=1 $\mu$ m; $\mathbf{B}$. The TEM image of the beginning of tail formation in spermatids, arrow: acrosome, asterisk: centriol, Scale bar=1 $\mu \mathrm{m}$; $\mathbf{C}$. The axoneme (arrows) and two mitochondrial derivatives (M) in the TEM image, Scale bar $=500 \mathrm{~nm}$. 


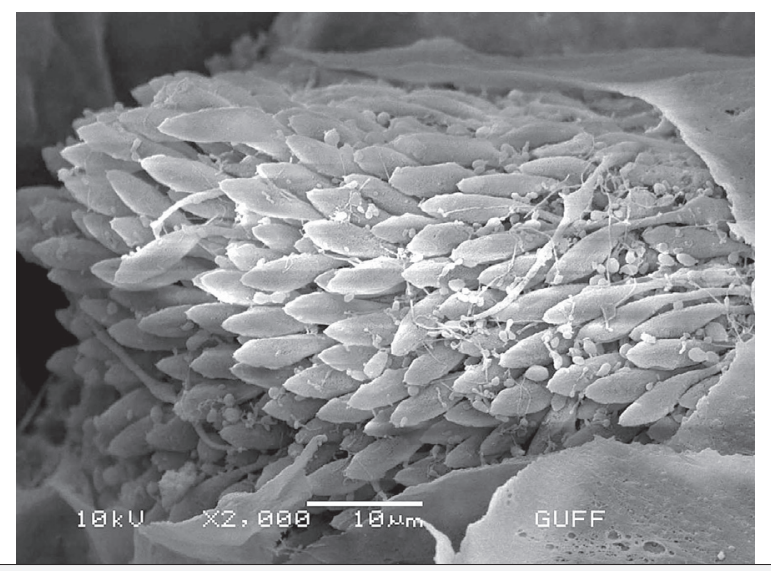

Figure 5. The late stage of spermatids with thin tail and a head beginning to elongate (SEM), Scale bar $=10 \mu \mathrm{m}$.
$19,2 \pm 1,7 \mu \mathrm{m}$ in length. The tail is quite thin and long compared to the head of the sperm. We detected many granules among the spermatozoa (Figure 6A).

The mature spermatozoa are packed together from the head to the holders to form bundles in cysts. This structure is called spermatodesm (Figure 7).

The accessory glands are tubular structures with closed end (Figures 1,8$)$. The male accessory glands of this species, P. ataturki consist of two different types of glandular tubule groups: the first group consisting of short and thin tubules and the second group consisting of long and thick tubules. The long tubes generally arise in front of the hindgut. Its outer surface is quite flat and surrounded by a trachea network. The epithelial layer is seen as a single-layered in cross sections in both groups of tubules. The difference between them is related to tubule lengths and di-

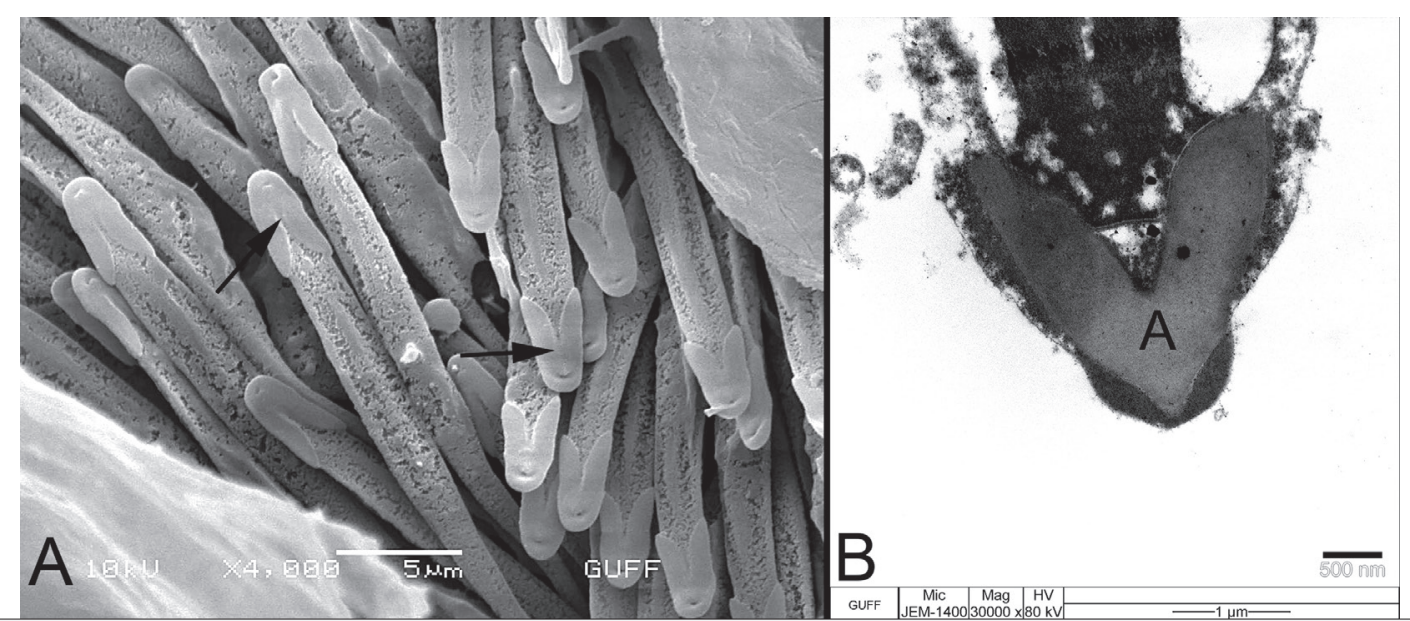

Figure 6. A. The SEM image of the mature sperm cell with head which completes elongation and long tail. Arrows: acrosome, Scale bar $=5 \mu \mathrm{m}$; B. The TEM image of the sperm head with acrosome (A), Scale bar $=1 \mu \mathrm{m}$.

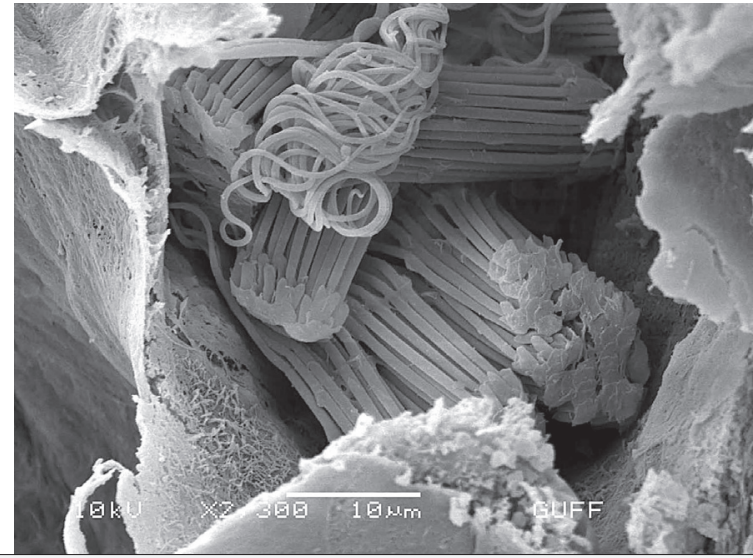

Figure 7. The SEM image of the mature spermatozoa packed together called spermatodesm, Scale bar $=10 \mu \mathrm{m}$.

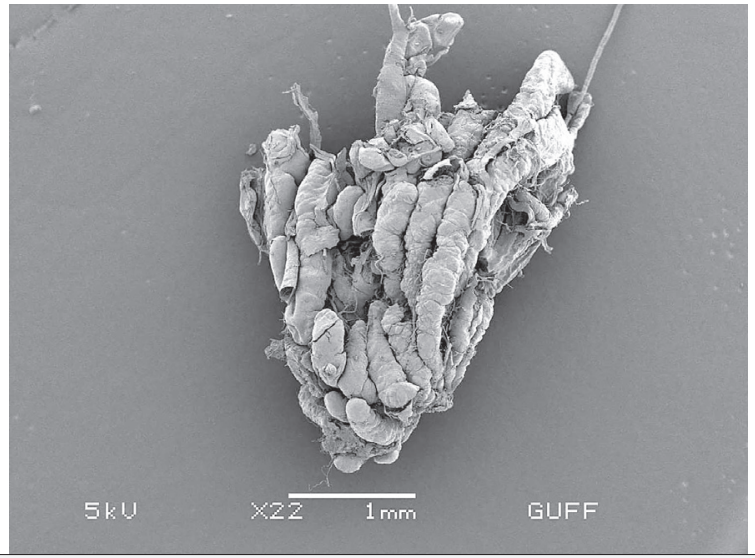

Figure 8 . The SEM image of the long accessory glands, Scale bar $=1 \mathrm{~mm}$. 

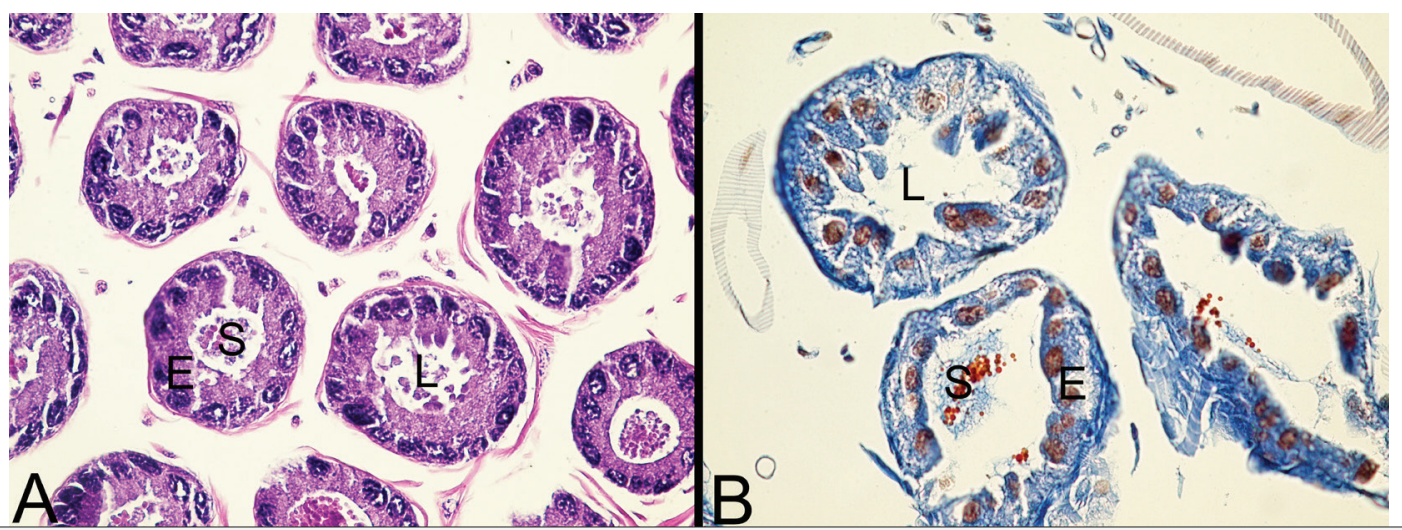

Figure 9. A. The light microscopic image of the cross sections of long accessory glands. E: epithelial cell layer, L: lumen, S: secretion of the accessory gland cells, H\&E staining, X400; B. The light microscopic image of the cross sections of long accessory glands. E: epithelial cell layer, L: lumen, S: secretion of the accessory gland cells, Mallory's trichrome staining, X400.

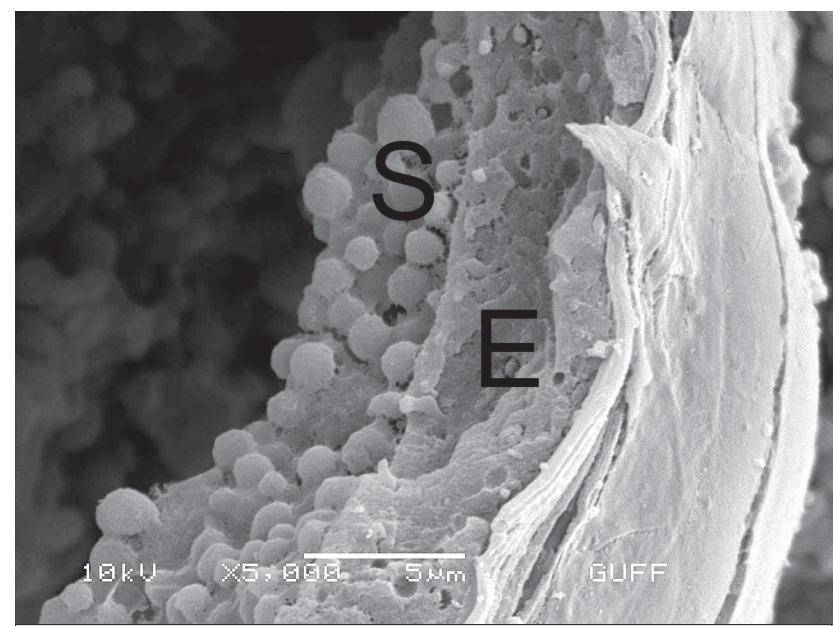

Figure 10. The SEM image of different sizes of secretory granules (S) in the lumen of the accessory glands. E: epithelial cell layer, Scale bar $=5 \mu \mathrm{m}$.

ameters. No significant difference was observed ultrastructurally. The shape of the cells in the epithelial layer is cubic or pyramidal (Figure 9A-B). Different sizes of secretory vesicles are observed in the lumen of the accessory gland tubules (Figure 10).

\section{DISCUSSION}

Male reproductive organs are generally similar in insect groups. However, some minor or major differences in these structures can be observed between different taxa. Many studies support the idea that many of the differences in these structures can be used as distinctive characters (4,5,16-19).

The elements of the reproductive system are usually testis, vasa deferentia, seminal vesicles, accessory glands, and ejaculatory duct in male insects, despite some differences. In accordance with this rule, two testes, two vas deferens, and ejaculatory duct have been observed in some insect species, such as Drepanosiphum platanoidis (Schrank), Euceraphis betulae (Koch), Macrosiphoniella tanacetaria (Kaltenbach), and Myzocallis walshii (Monell) from Aphididae (Homoptera) (20), Melanoplus sanguinipes (Fabricius, 1798) (18) and Pseudochorthippus parallelus parallelus (Zetterstedt, 1821) from Acrididae (Orthoptera) (4), Gryllus sigillatus (Walker, 1869) from Gryllidae (Orthoptera) (21). On the other hand, in addition to these structures, seminal vesicles are also found in some insect species such as Balclutha brevis Lindberg, 1954 from Cicadellidae (Hemiptera) (22). In P. ataturki, the situation is like the species in the first group, the seminal vesicle is absent.

Insects are the animal group with the most species diversity and high reproductive and survival ability $(23,24)$. Although insects generally have high reproductive capacity, the number of follicles in each testicle varies between various groups (25). Some species such as P. ataturki, P. parallelus parallelus (4), Poecilimon cervus Karabağ, 1950 (Orthoptera, Tettigoniidae) (26), and M. sanguinipes (18) has a large number of follicles in their testis, while some species has much less follicle number. For example, Orphullela punctata (De Geer, 1773) (Orthoptera, Acrididae) (2), larval Dione juno (Crameri 1779) (Lepidoptera, Nymphalidae) and larval Agraulis vanilla (Linnaeus, 1758) males have four follicles (27), Martarega betoi (Heteroptera, Notonectidae) (28) and Furcatopanorpa longihypovalva (Hua and Cai, 2009) (Mecoptera, Panorpidae) males have two follicles (29) and Tuberculatus eggleri Börner, E. betulae, D. platanoidis, M. walshii, and M. tanacetaria (Homoptera, Aphididae) males have three follicles (20) in their testes. One of the most important points we observed in this study we conducted is related to the sperm production capacity of each testis which has a big size. Because, we found a large number of follicles in each testis of $P$. ataturki. Similarly, the number of cysts in the follicles was also quite high. Pitnick and Markow also stated that daily sperm production is generally directly proportional to testicular size (30).

In addition to differences in testicular and follicle structure, sperm structure can also vary greatly between species. This 
is due to the fact that the sperm can have a suitable function and structure for successful fertilization of the insect $(24,31,32)$. These differences in sperm structures can be phylogenetically determinant (33).

The size, morphological and histological structure, and the results of histochemical staining of the male reproductive glands in insects may vary greatly (34). For example, there are different subtypes of accessory glands according to the diameter and length of the tubules in various orthopteroid families, such as three or nine in some Acrididae species, six in some Gryllidae species and two in some Tettigoniidae species $(21,35,36)$. The accessory glands of $P$. ataturki include two different types as long and short tubules, as in other Tettigoniidae species, such as P. cervus, Steropleurus elegans (Fischer), Bolivarius siculus (Fischer), Rhacocleis annulata Fieber, Tylopsis liliifolia Fabricius 1793, and Platycleis intermedia (Serville, 1838) (17,26,37). For this reason, the accessory glands of $P$. ataturki also show high similarity morphologically with the accessory glands of other Tettigoniidae species.

\section{CONCLUSION}

When all these results are evaluated, it can be said that the male reproductive system of $P$. ataturki, with some minor differences, closely resembles that of other species in the Tettigoniidae family. We hope that this study will serve as a basis for future studies on insect groups, especially species belonging to the order Orthoptera.

Acknowledgments: The authors owe Prof. Dr. Mustafa ÜNAL from Abant İzzet Baysal University a great debt of gratitude for diagnosis of the species studied and Gazi University Academic Writing and Research Center for their help and support in the proofreading of the current study.

Informed Consent: Written consent was obtained from the participants.

Peer Review: Externally peer-reviewed.

Author Contributions: Conception/Design of Study- D.A.P., I.P., Z.S.; Data Acquisition- D.A.P., I.P.; Data Analysis/InterpretationD.A.P., I.P., Z.S.; Drafting Manuscript- D.A.P., I.P., Z.S.; Critical Revision of Manuscript- D.A.P., I.P., Z.S.; Final Approval and Accountability- D.A.P., I.P., Z.S.

Conflict of Interest: Authors declared no conflict of interest.

Financial Disclosure: Authors declared no financial support.

\section{REFERENCES}

1. Gillott C. Male accessory gland secretions: Modulators of female reproductive physiology and behavior. Annu Rev Entomol 2003; 48: 163-84.

2. Silva DSM, Cossolin JFS, Pereira MR, Lino-Neto J, Sperber CF, Serrão JE. Male reproductive tract and spermatozoa ultrastructure in the grasshopper Orphulella punctata (De Geer, 1773) (Insecta, Orthoptera, Caelifera). Microsc Res Tech 2018; 81(2): 250-5.
3. Stephens K, Cardullo RA, Thaler CD. Culex pipiens sperm motility is initiated by a trypsin-like protease from male accessory glands. Mol Reprod Dev 2018; 85(5): 440-8.

4. Polat I, Amutkan Mutlu D, Ünal M, Suludere Z. Histology and ultrastructure of the testis and vas deferens in Pseudochorthippus parallelus parallelus (Orthoptera, Acrididae). Microsc Res Tech 2019; 82(9): 1461-70.

5. Polat I, Amutkan Mutlu D, Suludere Z. Accessory glands of male reproductive system in Pseudochorthippus parallelus parallelus (Zetterstedt, 1821) (Orthoptera: Acrididae): A light and electron microscopic study. Microsc Res Tech 2020; 83(3): 232-8.

6. White MJD. Patterns of spermatogenesis in grasshoppers. Aust J Zool 1954; 3: 222-6.

7. Chapman RF. The Insect Structure and Function. 5th ed. UK: Cambridge University Press; 2013.

8. Klowden MJ. Physiological Systems in Insects. 3rd ed. London, UK: Akademic Press; 2013.

9. Sharma V, Pandey AK, Kumar A, Misra S, Gupta HP, Gupta S, et al. Functional male accessory glands and fertility in Drosophila require novel ecdysone receptor. PLoS Genet 2017; 13(5): 1-26.

10. Gotoh A, Shigenobu S, Yamaguchi K, Kobayashi S, Ito F, Tsuji K. Transcriptome characterization of male accessory glands in ants to identify molecules involved in their reproductive success. Insect Mol Biol 2018; 27(2): 212-20.

11. Ünal M. Notes on Orthoptera of Western Turkey, with description of a new genus and four new species. J Orthoptera Res 1999; 8: 243-55.

12. Ünal M. Notes on Orthoptera of Western Turkey, with description of a new genus and four new species. J Orthoptera Res 2000; 9: 89-102.

13. Ünal M. Poecilimon Fischer (Orthoptera: Tettigoniidae: Phaneropterinae) species of the Batı Karadeniz region of Turkey, NW Anatolia. Trans Am Entomol Soc 2003; 129(3-4): 361-87.

14. Ünal M. Phaneropterinae (Orthoptera: Tettigoniidae) from Turkey and the Middle East. Trans Am Entomol Soc 2005; 131(3-4): 25-448.

15. Ünal M. Phaneropterinae (Orthoptera: Tettigoniidae) from Turkey and the Middle East II. Trans. Am Entomol Soc 2010; 136(1-2): 12583.

16. Liu X, Zhang J, Ma E, Guo Y. Studies on the phylogenetic relationship of Acridoidea based on the male follicle morphology (Orthoptera: Acridoidea). Orient Insects 2005; 39: 21-32.

17. Marchini D, Brundo MV, Sottile L, Viscuso R. Structure of male accessory glands of Bolivarus siculus (Fischer) (Orthoptera, Tettigoniidae) and protein analysis of their secretions. J Morphol 2009; 270: 880-91.

18. Jones N, Taub-Montemayor T, Rankin MA. Fluorescein-dextran sequestration in the reproductive tract of the migratory grasshopper Melanoplus sanguinipes (Orthoptera, Acridiidae). Micron 2013; 46: 80-4.

19. Viscuso R, Brundo MV, Marletta A, Vitale DGM. Fine structure of the male genital tracts of some Acrididae and Tettigoniidae (Insect: Orthoptera). Acta Zool 2015; 96(4): 418-27.

20. Vitale DGM, Brundo MV, Viscuso R. Morphological and ultrastructural organization of the male genital apparatus of some Aphididae (Insect, Homoptera). Tissue Cell 2011; 43: 271-82.

21. Nandchahal N. Reproductive organs of Gryllodes sigillatus (Walker) (Orthoptera: Gryllidae). J Nat Hist 1972; 6: 125-31.

22. Vitale DGM, Viscuso R, D'Urso V, Gibilras S, Sardella A, Marletta A, et al. Morphostructural analysis of the male reproductive system and DNA barcoding in Balclutha brevis Lindberg 1954 (Homoptera, Cicadellidae). Micron 2015; 79: 36-45.

23. O'woma OO, Chigozirim UP, Emmanuel O, Chukwuebuka EM. Reproductive and survival strategies utilized by insect. A review. Am J Zool Res 2016; 4(1): 1-6. 
24. Kotze RCM, Muller N, Du Plessis L, Van der Horst G. The importance of the insect sperm: Sperm ultrastructure of Hermetia illucens (black soldier fly). Tissue Cell 2019; 59: 44-50.

25. Sturm R. Stereological analysis of the sperm number in the testicular follicles of the Australian field cricket (Insecta: Orthoptera). Linz Biol Beit 2018; 50(1): 865-72.

26. Polat I. Poecilimon cervus Karabağ, 1950'un Sindirim, Boşaltım, Dişi ve Erkek Üreme Sisteminin Ültrastrüktürel Özellikleri. G.Ü., Fen Bilimleri Enstitüsü, Doktora Tezi. 2016.

27. Mari IP, Gigliolli AAS, Nanya S, Portela-Castro ALB. Histological and electron microscopy observations on the testis and spermatogenesis of the butterfly Dione juno (Cramer, 1779) and Agraulis vanilla (Linnaeus, 1758) (Lepidoptera: Nymphalidae). Micron 2018; 109: 11-21.

28. Novais AM, Dias G, Lino-Neto J. Testicular, spermatogenesis and sperm morphology in Martarega bentoi Heteroptera: Notonectidae). Arthropod Struct Dev 2017; 46: 635-43.

29. Zhang BB, Lyu QH, Hua BZ. Male reproductive system and sperm ultrastructure of Furcatopanorpa longihypovalva (Hua and Cai, 2009) (Mecoptera, Panorpidae) and its phylogenetic implication. Zool Anz 2016; 246: 41-6.
30. Pitnick S, Markow TA. Large-male advantages associated with costs of sperm production in Drosophila hydei, a species with giant sperm. Proc Natl Acad Sci 1994; 91(20): 9277-81.

31. Snook RR. Sperm in competiton: not playing by the numbers. Trends Ecol Evol 2005; 20: 46-53.

32. Werner M, Simmons LW. Insect sperm motility. Biol Rev 2008; 83: 191-2.

33. Dallai R, Gottardo M, Beutel RG. Structure and evolution of insect sperm: New interpretations in the age of phylogenomics. Annu Rev Entomol 2016; 61: 1-23.

34. Happ GM. Maturation of the male reproductive systems and its endocrine regulation. Annu Rev Entomol 1992; 37: 303-20.

35. Odhiambo TR. The architecture of the accessory reproductive glands of the male desert locust: III components of the muscular wall. Tissue Cell 1970; 2(2): 233-48.

36. Gallois D, Cassier P. Cytodifferentiation and maturation in the male accessory glands of Locusta migratoria migratoriodes (R. and F.) (Orthoptera: Acrididae). Int J Insect Morphol Embryol 1991; 20(3): 141-55.

37. Viscuso R, Narcisi L, Sottile L, Brundo MV. Role of male accessory glands in spermatodesm reorganization in Orthoptera Tettigonioidea. Tisssue Cell 2001; 33(1): 33-9. 